\title{
Dampak kebijakan pembangunan Pos Lintas Batas Negara (PLBN) Aruk di Desa Sebunga Kabupaten Sambas, Kalimantan
}

\section{Barat}

\section{Firdaus}

Universitas Tanjungpura, Indonesia

\section{INTISAR|}

Tulisan ini mendeskripsikan tentang dampak sektor sosial dan ekonomi serta faktor pendukung dan penghambat pembangunan Pos Lintas Batas Negara (PLBN) Aruk di Desa Sebunga, Kabupaten Sambas, Provinsi Kalimantan Barat. Pembaharuan operasi PLBN Aruk di Desa Sebunga yang saat ini menjadi pintu masuk lintas negara, selain untuk menjaga wilayah perbatasan tentunya PLBN Aruk dapat memberikan dampak bagi masyarakat dalam berbagai sektor seperti pada sektor sosial dan ekonomi. Penelitian ini menggunakan pendekatan kuantitatif deskriptif yang didukung oleh data lapangan berupa pendapat masyarakat terhadap dampak pembangunan PLBN Aruk. Data sekunder diperoleh langsung dari lembaga terkait dokumen dengan pembangunan PLBN Aruk. Teknik pengumpulan sampel menggunakan pemilihan sampel secara acak. Berdasarkan hasil penelitian, pembangunan PLBN Aruk di Desa Sebunga membawa dampak positif baik dalam bidang sosial maupun ekonomi. Dampak sosial yang dapat dirasakan masyarakat adalah kemudahan akesibilitas dan distribusi sarana dan prasarana publik seperti sarana pendidikan, sarana ibadah dan sarana transportasi. Selain itu sarana pengiriman barang baik pos maupun cargo lebih mudah dan murah untuk didapatkan. Pada sektor ekonomi masyarakat lebih mudah dan murah untuk mengakses komoditas pasar seperti sembako dan memiliki akses jual beli lebih mudah, sehingga membawa dampak daya saing masyarakat yang tinggi serta kesempatan kerja baik di sektor formal maupun informal.

\section{KATA KUNCI}

Dampak Kebijakan; Pembangunan; Pos Lintas Batas Negara (PLBN); Wilayah Perbatasan

\section{Korespodensi:}

Jurusan IImu Politik, Universitas Tanjungpura, Jl. Profesor Dokter H. Hadari Nawawi, Bansir Laut, Pontianak Tenggara, Kota Pontianak, Kalimantan Barat 78115.

Email: firdaus070991@gmail.com. 


\section{Pendahulluan}

$\mathrm{P}$ erbatasan negara merupakan manifestasi utama kedaulatan wilayah suatu negara. Perbatasan suatu negara memiliki peranan penting dalam penetapan batas wilayah kedaulatan, pemanfaatan sumber daya alam, menjaga keamanan dan keutuhan wilayah. Penentuan perbatasan negara dalam banyak hal ditentukan oleh proses historis, politik, hukum nasional dan internasional (Elisabeth, 2016). Adapun wilayah daratan Indonesia sendiri berbatasan dengan 3 (tiga) negara di 3 (tiga) pulau dan 4 (empat) provinsi, yaitu: Kalimantan Barat dan Kalimantan Timur berbatasan darat dengan Malaysia di negara bagian Serawak dan Sabah sepanjang 2004 km (Abubakar, 2006).

Secara fungsional, kawasan perbatasan memiliki nilai strategis dalam berbagai dimensi: kedaulatan negara, pertahanan, keamanan, dan ekonomi. Dewasa ini kesadaran warga masyarakat tentang pentingnya penataan dan optimalisasi potensi wilayah perbatasan semakin tinggi, menggantikan kesadaran lama bahwa wilayah perbatasan merupakan halaman belakang negara yang cukup dikelola ala kadarnya. Lahir berbagai kebijakan yang berdimensi kewilayahan maupun sektoral untuk mendukung perwujudan pembangunan kawasan perbatasan sebagai "halaman depan" negara, yaitu sebagai pintu gerbang aktivitas sosial budaya maupun interaksi ekonomi yang saling menguntungkan dengan negara tetangga (Elisabeth, 2016).

Warga negara Indonesia yang tinggal di sekitar perbatasan mengalami permasalahan kehidupan yang kompleks, di samping secara geografis mereka tinggal amat jauh dari ibukota negara, juga terisolir dari ibukota provinsi mereka sendiri. Tidak sedikit WNI di perbatasan hidup serba kekurangan dengan akses terhadap sumber daya-sumber daya ekonomi yang sulit dan terbatas jumlahnya. Pembangunan sosial di Kecamatan Sajingan Besar selama ini masih tertinggal jauh, sehingga memerlukan perhatian lebih serius dari pemerintah untuk mewujudkan kawasan perbatasan ibarat halaman depan dari sebuah negara. Orlando (2012) dalam studinya mengatakan bahwa dalam era globalisasi dewasa ini, isu pengembangan wilayah perbatasan (antar negara) khususnya di bagian utara Kalimantan Barat dan Kalimantan Timur, semakin krusial dan perlu mendapatkan perhatian serius dari pemerintah baik di tingkat Pusat maupun Daerah.

Permasalahan kependudukan di atas lebih diperparah lagi dengan adanya pengawasan pemerintah yang sangat kurang. Perbatasan antara Indonesia dengan Malaysia di Kalimantan Barat dan Kalimantan Timur sangat panjang dan luas, namun hanya diawasi oleh pos lintas batas, pos pengawasan dan petugas yang tidak banyak serta fasilitas teknologi pengamanan perbatasan yang kurang mumpuni. Adanya pergolakan politik internal yang tidak stabil di daerah perbatasan, maka kondisi keamanan di perbatasan tergolong rawan. Terlebih lagi, masuknya imigran gelap ke daerah Indonesia, atau dari Indonesia ke negeri tetangga secara illegal atau sebaliknya dari bentuk kejahatan lintas negara, seperti illegal logging, illegal fishing, human traficking, serta perdagangan narkotika \& psikotropika dan lain sebagainya memiliki potensi kejadian juga amat besar. 
Pengelolaan kawasan perbatasan di Indonesia selama ini dihadapkan pada ua isu strategis, yaitu isu pengelolaan batas wilayah negara dan isu pengelolaan kawasan perbatasan. Belum optimalnya pengembangan, pemanfaatan potensi dan kurang tersedianya sarana/prasarana dasar di kawasan perbatasan, merupakan permasalahan umum yang terjadi dan dihadapi hampir di semua kawasan perbatasan wilayah negara Indonesia (Evaluasi dan Pengawasan Pengelolaan Perbatasan Negara, 2015). Hal tersebut menyebabkan kawasan perbatasan senantiasa tertinggal dan terisolir, tingkat kesejahteraan masyarakatnya yang rendah dan aksesibilitas yang kurang, terutama akses kawasan perbatasan dengan pusat pemerintahan, pusat-pusat pelayanan publik, atau wilayah lain yang relatif lebih maju. di pihak lain, wilayah perbatasan Malaysia sudah dilakukan perbaikan infrastruktur kebudayaan, rekreasi dan Ruang Terbuka Hijau (RTH), sehingga perekonomian pun menggeliat dan mampu meningkatkan pendapatan dari bidang pariwisata.

Merespon situasi tersebut, sebagai terobosan bagi pengelolaan kawasan perbatasan secara terintegrasi, Undang-Undang Nomor 43 Tahun 2008 Tentang Wilayah Negara diterbitkan. UndangUndang ini memberi mandat bagi pembentukan Badan Nasional Pengelola Perbatasan (BNPP) di tingkat pusat dan daerah, dengan tugas menetapkan kebijakan program pembangunan perbatasan, rencana kebutuhan anggaran, mengkoordinasikan pelaksanaan, dan melaksanakan evaluasi serta pengawasan terhadap pengelolaan batas wilayah negara dan kawasan perbatasan. Adapun pelaksana teknis pembangunan dilakukan oleh Kementerian/Lembaga dan Pemerintah Daerah yang menjadi anggota dari Badan tersebut (Evaluasi dan Pengawasan Pengelolaan Perbatasan Negara, 2015).

Terbentuknya BNPP merupakan usaha yang dilakukan pemerintah dalam upaya percepatan penyelesaian masalah perbatasan negara serta menjadikan kawasan perbatasan sebagai serambi depan negara, yang berorientasi outward looking atau pintu gerbang aktivitas ekonomi dan perdagangan dengan negara tetangga. BNPP mengemban visi mewujudkan tata kelola batas negara dan kawasan perbatasan yang aman, tertib, maju dan menjadi pusat pertumbuhan ekonomi serta menjamin kesejahteraan rakyat dan keutuhan Negara Kesatuan Republik Indonesia.

Dengan latar belakang seperti di atas, maka tulisan ini bertujuan secara khsusu untuk melihat dampak kebijakan pembangunan Pos Lintas Batas Negara (PLBN) Aruk Desa Sebunga Kecamatan Sajingan Besar Kabupaten Sambas Kalimantan Barat terhadap pertumbuhan sektor sosial dan ekonomi. Selain itu, tulisan ini juga bertujuan untuk menjelaskan faktor pendukung dan penghambat dari keberfungsian Pos Lintas Batas Negara (PLBN) Aruk Desa Sebunga Kecamatan Sajingan Besar Kabupaten Sambas Kalimantan Barat terkait pertumbuhan sektor sosial dan ekonomi.

Adapun artikel ini didukung oleh metode kuantitatif deskriptif selama proses penelitian. Studi penelitian ini dilakukan di wilayah perbatasan Indonesia-Malaysia, tepatnya di Dusun Aruk Desa Sebunga Kecamatan Sajingan Besar Kabupaten Sambas. Teknik pengumpulan dilakukan melalui survey, observasi dan wawancara. Data yang terkumpul kemudian dikategorikan dan dikonfirmasi kembali kepada informan. Teknik survei dilakukan dengan menggunakan kuesioner yang ditanyakan 
kepada 97 sampel penelitian. Sedangkan data wawancara dan observasi dilakukan dengan penentuan informan oleh peneliti. Selain data primer juga dilengkapi dengan data sekunder dari berbagai sumber referensi, seperti; buku, dokumen pemerintah dan jurnal ilmiah. Dokumentasi yang dikumpulkan di lapangan berupa foto-foto penelitian.

\section{Dampak Sosial-Ekonomi Sosial Kebijakan Pembangunan PLBN Aruk}

Untuk melihat sejauh mana dampak sosial dari pembangunan PLBN Aruk, maka survey berikut ini bisa memberikan gambaran sederhana.

Tabel 1: Dimensi Sosial Sebelum Dibangunnya PLBN Aruk

\begin{tabular}{|c|c|c|c|c|c|c|c|}
\hline \multirow[t]{2}{*}{ Indikator Sosial } & \multicolumn{5}{|c|}{$\begin{array}{l}\text { Frekuensi Jawaban responden untuk } \\
\text { indikator Sosial (\%) }\end{array}$} & \multirow{2}{*}{$\begin{array}{l}\text { Indeks } \\
\qquad \sum \mathrm{fx}\end{array}$} & \multirow[t]{2}{*}{ Kategori } \\
\hline & 1 & 2 & 3 & 4 & 5 & & \\
\hline $\begin{array}{l}\text { Mendapatkan sarana pendidikan } \\
\text { formal }\end{array}$ & 11,34 & 14,43 & 41,24 & 30,93 & 2,06 & 59,59 & Sedang \\
\hline Mendapatkan sarana ibadah & 6,19 & 16,49 & 34,02 & 31,96 & 11,34 & 65,15 & Sedang \\
\hline $\begin{array}{l}\text { Mendapatkan sarana } \\
\text { transportasi umum }\end{array}$ & 11,34 & 16,49 & 30,93 & 34,02 & 7,22 & 61,86 & Sedang \\
\hline $\begin{array}{l}\text { Mendapatkan kualitas sarana } \\
\text { jalan }\end{array}$ & 7,22 & 10,30 & 43,30 & 31,96 & 7,22 & 64,33 & Sedang \\
\hline Ketersediaan MCK umum & 10,31 & 20,62 & 39,18 & 25,77 & 4,12 & 58,55 & Sedang \\
\hline $\begin{array}{l}\text { Ketersediaan sarana jembatan } \\
\text { penghubung }\end{array}$ & 10,31 & 16,49 & 39,18 & 31,96 & 2,06 & 59,79 & Sedang \\
\hline $\begin{array}{l}\text { Ketersediaan sarana terminal } \\
\text { umum }\end{array}$ & 11,34 & 19,58 & 39,18 & 27,84 & 2,06 & 57,94 & Sedang \\
\hline $\begin{array}{l}\text { Ketersediaan sarana jasa pos } \\
\text { dan cargo }\end{array}$ & 12,36 & 18,56 & 39,18 & 27,84 & 2,06 & 57,74 & Sedang \\
\hline \multicolumn{6}{|c|}{ Rata-rata } & 60,62 & Sedang \\
\hline
\end{tabular}

Sumber: Data primer yang diolah, 2018.

Tabel di atas memperlihatkan indeks rata-rata pembangunan sosial pada kondisi sebelum keberfungsian PLBN Aruk sebesar 60,62 (sedang). Indikator yang memiliki nilai indeks tertinggi adalah "Setelah adanya PLBN Aruk untuk mendapatkan sarana tempat ibadah dibandingkan sebelumnya lebih mudah", yaitu sebesar 65,15 (sedang) dan yang terendah adalah indikator "Setelah adanya PLBN Aruk, kebutuhan untuk melakukan pos dan cargo ke seluruh wilayah Inonesia menjadi lebih mudah dibandingkan sebelumnya", yaitu sebesar 57,74 (sedang). Fenomena semacam ini memperlihatkan bahwa seluruh indikator variabel pembangunan sosial yang berjumlah 8 (delapan) tersebut, masih sangat memerlukan untuk ditingkatkan secara intensif 
dan berkesinambungan, sehingga nantinya kawasan perbatasan Aruk semakin berkembang sebagaimana kawasan perbatasan dari negara tetangga.

Tabel 2 Dimensi Sosial Sesudah Dibangunnya PLBN Aruk

\begin{tabular}{|c|c|c|c|c|c|c|c|}
\hline \multirow[t]{2}{*}{ Indikator Sosial } & \multicolumn{5}{|c|}{$\begin{array}{l}\text { Frekuensi Jawaban responden untuk } \\
\text { indikator Sosial (\%) }\end{array}$} & \multirow{2}{*}{$\begin{array}{l}\text { Indeks } \\
\qquad \mathrm{fx}\end{array}$} & \multirow[t]{2}{*}{ Kategori } \\
\hline & STS & TS & $\mathbf{N}$ & S & SS & & \\
\hline $\begin{array}{l}\text { Mendapatkan sarana pendidikan } \\
\text { formal }\end{array}$ & 4,12 & 6,19 & 48,45 & 38,14 & 3,10 & 65,98 & Sedang \\
\hline Mendapatkan sarana ibadah & 6,19 & 16,49 & 31,96 & 34,02 & 11,34 & 65,57 & Sedang \\
\hline $\begin{array}{l}\text { Mendapatkan sarana transportasi } \\
\text { umum }\end{array}$ & 9,28 & 15,46 & 30,93 & 36,08 & 8,25 & 63,71 & Sedang \\
\hline Mendapatkan kualitas sarana jalan & 5,15 & 9,28 & 44,33 & 34,02 & 7,22 & 65,78 & Sedang \\
\hline Ketersediaan MCK umum & 1,03 & 10,31 & 43,30 & 38,14 & 7,22 & 68,04 & Sedang \\
\hline $\begin{array}{l}\text { Ketersediaan sarana jembatan } \\
\text { penghubung }\end{array}$ & 1,03 & 16,50 & 34,02 & 38,14 & 10,31 & 68,04 & Sedang \\
\hline $\begin{array}{l}\text { Ketersediaan sarana terminal } \\
\text { umum }\end{array}$ & 3,09 & 13,40 & 45,37 & 37,11 & 1,03 & 63,92 & Sedang \\
\hline $\begin{array}{l}\text { Ketersediaan sarana jasa pos dan } \\
\text { cargo }\end{array}$ & 3,09 & 11,34 & 47,43 & 36,08 & 2,06 & 64,54 & Sedang \\
\hline \multicolumn{6}{|c|}{ Rata-rata } & 65,70 & Sedang \\
\hline
\end{tabular}

Sumber: Data primer yang diolah, 2018.

Tabel di atas memperlihatkan indeks rata-rata pembangunan sosial pada kondisi sesudah keberfungsian PLBN Aruk sebesar 65,70 (sedang). Indikator yang memiliki nilai indeks tertinggi adalah "Setelah adanya PLBN Aruk, ketersediaan sarana MCK dibandingkan sebelumnya lebih bagus", dan "Setelah adanya PLBN Aruk, ketersediaan sarana jembatan penghubung dibandingkan sebelumnya lebih bagus", yaitu masing-masing sebesar 68,04 (sedang), dan yang terendah adalah indikator "Setelah adanya PLBN Aruk untuk mendapatkan sarana angkutan umum dibandingkan sebelumnya lebih mudah", yaitu sebesar 63,71 (sedang). Fenomena semacam ini memperlihatkan bahwa seluruh indikator variabel pembangunan sosial yang berjumlah 8 (delapan) tersebut, masih sangat memerlukan untuk ditingkatkan secara intensif dan berkesinambungan, sehingga kawasan Aruk menjadi tidak tertinggal dibandingkan dengan kawasan perbatasan tetangga sebelah ataupun dengan kawasan PLBN lainnya, baik di Kalimantan Barat, Kalimantan Timur, NTT maupun Papua. Dari tabel 1 dan tabel 2, maka diperoleh kesimpulan bahwa telah terjadi peningkatan persepsi warga masyarakat terhadap dimensi sosial di kawasan PLBN Aruk, dari semula sebesar rata-rata 60,62 menjadi 65,70.

Sedangkan untuk dampak ekonomi dari pembangunan PLBK, dapat dilihat pada tabel di bawah ini. 
Tabel 3 Dimensi Ekonomi Kondisi Sebelum Dibangun PLBN Aruk

\begin{tabular}{|c|c|c|c|c|c|c|c|}
\hline \multirow[t]{2}{*}{ Indikator Ekonomi } & \multicolumn{5}{|c|}{$\begin{array}{c}\text { Frekuensi Jawaban responden untuk } \\
\text { indikator Ekonomi (\%) }\end{array}$} & \multirow{2}{*}{$\begin{array}{l}\text { Indeks } \\
\qquad \sum \mathrm{fx}\end{array}$} & \multirow[t]{2}{*}{ Kategori } \\
\hline & 1 & 2 & 3 & 4 & 5 & & \\
\hline $\begin{array}{l}\text { Kemudahan mendapatkan modal } \\
\text { usaha }\end{array}$ & 10,31 & 20,62 & 39,18 & 25,77 & 4,12 & 58,55 & Sedang \\
\hline $\begin{array}{l}\text { Kemudahan mendapatkan sarana } \\
\text { pasar }\end{array}$ & 11,34 & 21,65 & 38,14 & 22,68 & 6,19 & 58,15 & Sedang \\
\hline $\begin{array}{l}\text { Kemudahan mendapatkan } \\
\text { sembako lebih mudah }\end{array}$ & 8,25 & 23,70 & 39,18 & 21,65 & 7,22 & 59,18 & Sedang \\
\hline $\begin{array}{l}\text { Kemudahan mendapatkan } \\
\text { sembako lebih murah }\end{array}$ & 6,19 & 36,08 & 40,21 & 12,37 & 5,15 & 54,84 & Sedang \\
\hline $\begin{array}{l}\text { Kemudahan mencapai lokasi } \\
\text { penjualan sembako }\end{array}$ & 2,06 & 37,11 & 41,24 & 14,44 & 5,15 & 56,70 & Sedang \\
\hline Harga di pasar lebih terjangkau & 6,19 & 24,74 & 45,36 & 16,49 & 7,22 & 58,76 & Sedang \\
\hline Kemampuan daya beli meningkat & 7,22 & 22,68 & 44,33 & 17,52 & 8,25 & 59,38 & Sedang \\
\hline Daya saing warga semakin tinggi & 9,28 & 20,62 & 39,18 & 19,58 & 11,34 & 60,62 & Sedang \\
\hline $\begin{array}{l}\text { Peluang mendapatkan pekerjaan } \\
\text { formal semakin tinggi }\end{array}$ & 11,34 & 19,59 & 40,21 & 19,58 & 9,28 & 59,17 & Sedang \\
\hline $\begin{array}{l}\text { Peluang mendapatkan pekerjaan } \\
\text { informal semakin tinggi }\end{array}$ & 12,37 & 18,56 & 41,24 & 20,62 & 7,22 & 58,36 & Sedang \\
\hline $\begin{array}{l}\text { Peluang mendapatkan pekerjaan } \\
\text { di sektor pertanian semakin } \\
\text { tinggi }\end{array}$ & 8,25 & 23,71 & 38,14 & 22,68 & 7,22 & 59,38 & Sedang \\
\hline $\begin{array}{l}\text { Peluang mendapatkan pekerjaan } \\
\text { di sektor kehutanan semakin } \\
\text { tinggi }\end{array}$ & 9,28 & 24,74 & 36,08 & 21,65 & 8,25 & 58,97 & Sedang \\
\hline \multicolumn{6}{|c|}{ Rata-rata } & 58,51 & Sedang \\
\hline
\end{tabular}

Sumber: Data primer yang diolah, 2018.

Tabel di atas memperlihatkan indeks rata-rata pembangunan ekonomi pada kondisi sebelum keberfungsian PLBN Aruk sebesar 58,51 (sedang). Indikator yang memiliki nilai indeks tertinggi adalah "Setelah adanya PLBN Aruk, daya saing masyarakat semakin tinggi", yaitu sebesar 60,62 (sedang) dan yang terendah adalah indikator "Setelah adanya PLBN Aruk, untuk memperoleh sembako dibandingkan sebelumnya lebih murah", yaitu sebesar 54,84 (sedang). Fenomena semacam ini memperlihatkan bahwa seluruh indikator variabel pembangunan ekonomi yang berjumlah 12 (dua belas) tersebut, masih memerlukan peningkatan secara lebih intensif dan berkesinambungan, melalui pendekatan yang integral oleh pemerintah pusat. 
Tabel 4 Dimensi Ekonomi Sesudah Dibangunnya PLBN Aruk

\begin{tabular}{|c|c|c|c|c|c|c|c|}
\hline \multirow[t]{2}{*}{ Indikator Ekonomi } & \multicolumn{5}{|c|}{$\begin{array}{c}\text { Frekuensi Jawaban responden untuk } \\
\text { indikator Ekonomi (\%) }\end{array}$} & \multirow{2}{*}{$\begin{array}{l}\text { Indeks } \\
\qquad \mathrm{fx}\end{array}$} & \multirow[t]{2}{*}{ Kategori } \\
\hline & 1 & 2 & 3 & 4 & 5 & & \\
\hline $\begin{array}{l}\text { Kemudahan mendapatkan modal } \\
\text { usaha }\end{array}$ & 8,25 & 8,24 & 39,18 & 41,24 & 3,09 & 64,54 & Sedang \\
\hline $\begin{array}{l}\text { Kemudahan mendapatkan sarana } \\
\text { pasar }\end{array}$ & 2,06 & 11,34 & 46,40 & 35,05 & 5,15 & 65,98 & Sedang \\
\hline $\begin{array}{l}\text { Kemudahan mendapatkan } \\
\text { sembako lebih mudah }\end{array}$ & 1,03 & 13,40 & 43,31 & 38,14 & 4,12 & 66,18 & Sedang \\
\hline $\begin{array}{l}\text { Kemudahan mendapatkan } \\
\text { sembako lebih murah }\end{array}$ & 1,03 & 16,49 & 47,42 & 24,74 & 10,32 & 65,37 & Sedang \\
\hline $\begin{array}{l}\text { Kemudahan mencapai lokasi } \\
\text { penjualan sembako }\end{array}$ & 2,06 & 14,43 & 40,21 & 39,18 & 4,12 & 65,77 & Sedang \\
\hline Harga di pasar lebih terjangkau & 1,03 & 16,50 & 38,14 & 41,24 & 3,09 & 65,77 & Sedang \\
\hline Kemampuan daya beli meningkat & 7,22 & 16,49 & 39,18 & 36,08 & 1,03 & 61,44 & Sedang \\
\hline Daya saing warga semakin tinggi & 2,06 & 21,66 & 38,14 & 35,05 & 3,09 & 63,09 & Sedang \\
\hline $\begin{array}{l}\text { Peluang mendapatkan pekerjaan } \\
\text { formal semakin tinggi }\end{array}$ & 1,03 & 17,53 & 44,33 & 28,87 & 8,24 & 65,15 & Sedang \\
\hline $\begin{array}{l}\text { Peluang mendapatkan pekerjaan } \\
\text { informal semakin tinggi }\end{array}$ & 1,03 & 13,40 & 52,58 & 29,90 & 3,09 & 64,12 & Sedang \\
\hline $\begin{array}{l}\text { Peluang mendapatkan pekerjaan } \\
\text { di sektor pertanian semakin tinggi }\end{array}$ & 1,03 & 18,56 & 32,99 & 43,30 & 4,12 & 66,18 & Sedang \\
\hline $\begin{array}{l}\text { Peluang mendapatkan pekerjaan } \\
\text { di sektor kehutanan semakin tinggi }\end{array}$ & 4,12 & 16,48 & 27,84 & 43,40 & 8,25 & 67,09 & Sedang \\
\hline \multicolumn{6}{|c|}{ Rata-rata } & 65,06 & Sedang \\
\hline
\end{tabular}

Sumber: Data primer yang diolah, 2018.

Tabel di atas memperlihatkan indeks rata-rata pembangunan ekonomi pada kondisi sesudah keberfungsian PLBN Aruk sebesar 65,06 (sedang). Indikator yang memiliki nilai indeks tertinggi adalah "Setelah adanya PLBN Aruk, peluang dalam mendapatkan kesempatan kerja di sektor kehutanan semakin tinggi", yaitu sebesar 67,09 (sedang), dan yang terendah adalah indikator "Setelah adanya PLBN Aruk, daya beli masyarakat semakin menguat", yaitu sebesar 61,44 (sedang). Fenomena di atas memperlihatkan bahwa seluruh indikator variabel pembangunan ekonomi yang berjumlah 12 (dua belas) tersebut, sangat memerlukan peningkatan secara lebih intensif dan berkesinambungan melalui konsep kebijakan pembangunan perbatasan yang integral. Adapun harapannya adalah kawasan PLBN Aruk menjadi kawasan yang berkembang dengan menampakkan kawasan yang menggeliat perekonomiannya, serta tidak tertinggal dibandingkan dengan kawasan 
perbatasan lainnya. Dari tabel 3 dan tabel 4 juga diperlihatkan telah terjadinya peningkatan pembangunan di bidang ekonomi antara kondisi sebelum dan kondisi sesudah keberfungsian PLBN Aruk, dari semula rata-rata sebesar 58,51 menjadi sebesar 65,06 (walaupun sama-sama dalam kategori "sedang").

\section{Faktor Pendukung dan Penghambat Pertumbuhan Sosial-Ekonomi}

Ada empat faktor yang mendukung pertumbuhan sektor sosial dan ekonomi di wilayah PLBN Aruk. Pertama, faktor sumber daya. Dukungan sumber daya dari pengelola PLBN Aruk kepada warga selama ini tergolong cukup tinggi. Sebagai contoh; pembangunan infrastruktur jalan, penerangan umum, ketersediaan air dan kenyamanan. Namun masih terdapat beberapa hal pokok dan mendasar yang pihak pengelola belum mampu memberikan dukungan kepada warga sekitar perbatasan, baik secara langsung maupun tidak langsung.

Belum terbangunnya terminal truck, sehingga PLBN Aruk belum dapat dilintasi bus dan truck membuat arus dan volume perdagangan antara kedua negara berlangsung stagnan, walaupun infrastruktur Pos Lintas Batas Negara telah dibangun megah. Adanya dukungan positif dan massif dari pemerintah dalam aspek permodalan akan sangat membantu warga menekuni iklim usaha perdagangan. Pihak pengelola bekerjasama dengan perbankan memang sedang mengusahakan pinjaman finansial bagi warga masyarakat, namun untuk sementara ini belum mampu diwujudkan, karena pembangunan gedung perbankannya saja belum selesai. Rencana pertengahan Juli 2018 ini, gedung perbankan akan selesai dibangun, sehingga akan seera beroperasional secara full time.

Kedua, faktor kompetensi sumber daya manusia dari pihak pengelola PLBN Aruk dalam melakukan pembinaan kepada warga. Dalam rangka menciptakan iklim kebersamaan antara pihak pengelola PLBN Aruk dengan warga masyarakat sekitar, maka dibentuk beberapa kegiatan, di antaranya adalah pembinaan sosial dan keamanan, dengan harapan agar di lingkungan masyarakat dapat terjalin lingkungan masyarakat yang aman, tertib, disiplin dan terkendali. Dukungan sumber daya manusia (SDM) pengelola wilayah PLBN Aruk menjadi hal yang penting dalam mengelola wilayah perbatasan.

Ketiga, dukungan informasi dan teknologi. Dukungan pihak pengelola PLBN Aruk kepada warga dalam hal informasi dan teknologi secara konkrit adalah keberfungsian wifi di kawasan PLBN Aruk untuk digunakan gratis oleh warga masyarakat, yang seiring dibangunnya PLBN Aruk mulai menggandrungi handphone android. Sebelum ini PLBN Aruk dibangun sebagaimana sekarang ini, penggunaan handphone android tergolong masih sangat jarang, namun seiring dengan adanya pembangunan PLBN Aruk yang notabene juga disertakan pemasangan wifi public, maka penggunaan handphone android di kalangan warga masyarakat meningkat pesat. Hal ini ditandai dengan semakin banyaknya counter dengan usaha-usaha penjualan pulsa di sekitar kawasan perbatasan Aruk. Hal ini sejalan dengan keterangan Supriadi, bahwa "Dukungan informasi sampai saat ini dari mulut ke mulut, informasi secara internet masih wifi lokal saja. Secara eksternal, semacam koran-koran lokal, datang ke sini dibawa masyarakat semacam LSM". 
Keempat, sikap positif pihak pengelola PLBN Aruk terhadap pengembangan perekonomian warga. Pihak pengelola sangat memahami kebutuhan warga masyarakat, oleh karena itu pihak pengelola bekerjasama dengan Bank Mandiri dan Bank BRI sedang melakukan pembangunan sarana gedung perbankan di kawasan perbatasan. Di pihak lain, dalam rangka mendukung iklim pertukaran barang dan jasa yang lebih tinggi antar kedua wilayah negara, maka pihak pengelola juga sedang membangun terminal bus dan truck, juga mengaspal jalan dari kampungkampung menuju Aruk dan sebaliknya, sehingga truck dan bus bisa melintasi PLBN Aruk hingga ke pedalaman.

Hal ini sejalan dengan keterangan dari Manto Saidi bahwa "Khusus untuk di PLBN Aruk, mobil belum bisa melintas, sejauh yang saya pahami dengan komparasi ke Entikong dan Nanga Badau, dua PLBN itu sudah bisa dilintasi oleh kendaraan. Di Entikong, bus-bus besar, truck, dan kendaraan pribadi sudah bisa lewat". Di Badau bahkan kontainer atau tangki CPO kelapa sawit dengan kapasitas tertinggi, sudah bisa lewat juga melalui PLBN Badau. Di Aruk belum bisa, ketika ini penulis telusuri ternyata, perbedaan PLBN Aruk dengan kedua PLBN yang sudah bisa dilewati hanya satu, yaitu kehadiran petugas Perhubungan Darat Provinsi Kalimantan Barat. Hal inilah yang tidak hadir di Kalimantan Barat".

Sikap positif petugas pengelola PLBN Aruk terhadap warga masyarakat antara lain bisa diwujudkan dengan ditingkatkannya penindakan dan penegakan hukum secara lebih tegas dan intensif terhadap pelanggaran perlintasan perbatasan. Sebagaimana dikatakan Supriadi, bahwa "Sikap positif; kami dukung untuk meningkatkan lagi perdagangan supaya mereka lebih giat memproduksi kebutuhan barang lokal ke Malaysia, misal produk kerajinan perkebunan. Kita juga upayakan kerjasama dari dinas terkait. Sikap negatif tidak ada. Barang yang ilegal, tidak ada. Demi kemajuan dan keamanan kita tindak tegas pelanggaran". Kiprah petugas pengelola yang semakin tegas terhadap pelaku pelanggaran pelintas batas, sekiranya akan juga mendapatkan dukungan dalam rangka terciptanya iklim perbatasan yang disiplin dan nyaman.

Sedangkan untuk faktor yang menghambat sektor sosial dan ekonomi pada PLBN Aruk berdasarkan temuan penelitian di lapangan bisa dikategorikan dalam 3 hal, yakni faktor komunikasi, faktor infrastruktur, dan faktor struktur birokrasi. Pertama, faktor komunikasi. Kemampuan pengelola dalam memberikan pengetahuan kepada warga (target) mengenai keberadaan PLBN Aruk sebagaimana diakui oleh Supriadi, Kepala Subid Fasilitasi Pelayanan PLBN Aruk, bahwa "Kemampuan pengelola dalam memberikan pengetahuan kepada warga mengenai keberadaan PLBN, status kami dipekerjakan BNPP, tergolong cukup bagus. Kami sering mengadakan sosialisasi Aruk Sajingan. Kami juga membaur kepada masyarakat memberikan pelayanan, khususnya mengenai arus barang dan orang dalam bentuk pelatihan semacam sosialisasi ke masyarakat dan pedagang. Selain dari mulut ke mulut, ada sosialisasi diundang perangkat desa bekerjasama dengan pihak Kecamatan, di mana masyarakat dilibatkan sebelum kedatangan Presiden".

Diharapkan dengan adanya pengetahuan yang update mengenai PLBN Aruk, warga masyarakat akan lebih bersikap positif dan kondusif bagi kelangsungan PLBN Aruk di kemudian hari. Pada kenyataannya, walaupun tranformasi pengetahuan tentang keberadaan PLBN Aruk sudah diberikan 
kepada warga masyarakat, akan tetapi secara a-quo pengetahuan masyarakat mengenai PLBN Aruk masih tergolong rendah. Terbukti dari keberfungsian PLBN Aruk selama ini meliputi bidang apa saja, mayoritas warga masyarakat tidak mengetahuinya. Hal ini sangat berbeda dengan apa yang dikatakan oleh Bupati Sambas mengenai keberfungsian PLBN Aruk pasca diresmikan Jokowi, meliputi bidang "Imigrasi, costume, karantina, kepolisian dan tentara di perbatasan, namun perhubungan belum ada". Hal ini sejalan keterangan Manto Saidi bahwa "Kantor Imigrasi, Beacukai, Perdagangan, Balai karantina yang meliputi karantina pertanian, karantina perikanan dan karantina kesehatan, keberadaan kepolisian dan TNI di perbatasan, namun belum disertakan aparat yang berkompeten dalam hal perhubungan darat, tidak sebagaimana di PLBN Nanga Badau yang sudah menyertakan Dinas Perhubungan Darat".

Dari uraian di atas diketahui bahwa program komunikasi strategis yang dirancang khusus untuk memberikan pemahaman secara lebih kepada warga masyarakat mengenai PLBN Aruk belum pernah dilakukan secara matang. Belum terjalinnya program komunikasi strategis ini menurut Manto Saidi, disebabkan karena ketiadaan dukungan dari badan atau institusi yang independen dan integral, yang memiliki kewenangan operasional secara menyeluruh terhadap pengelolaan PLBN Aruk.

Ketiadaan badan yang integral dalam pengelolaan PLBN Aruk, maka segala aspek terkait, baik mengenai perdagangan jasa dan barang, juga perlintasan orang dan barang secara tradisional dan internasional, akan mengalami gangguan, karena komunikasi dan koordinasi sangat sulit untuk dicapai oleh petugas terkait. Fenomena seperti inilah yang menjadikan pengelola PLBN Aruk terasa cukup jauh dari harapan masyarakat, karena petugas yang ditempatkan di PLBN Aruk, semuanya adalah pegawai pusat, bukan pegawai daerah, sehingga kurang cakap dalam pengelolaan kewilayahan.

Kedua, faktor infrastruktur. Infrastruktur adalah segala yang merupakan penunjang utama terselenggaranya suatu proses (usaha, pembangunan, proyek, dan lain-lain). World Bank membagi infrastruktur menjadi 3 (tiga) kategori, yaitu:

1) Infrastruktur ekonomi, merupakan infrastruktur fisik yang diperlukan untuk menunjang aktivitas ekonomi, meliputi: public utilities (listrik, telekomunikasi, air, sanitasi, gas), public work (jalan, bendungan, kanal, irigasi dan drainase) dan sektor transportasi (jalan, rel, pelabuhan, lapangan terbang dan sebagainya);

2) Infrastruktur sosial, meliputi: pendidikan, kesehatan, perumahan dan rekreasi;

3) Infrastruktur administrasi, meliputi: penegakan hukum, kontrol administrasi dan koordinasi.

Terlepas dari keberfungsian PLBN Aruk selama ini yang belum optimal dari aspek komunikasi, namun setidaknya dengan adanya pembangunan infrastruktur, efisiensi dan efektivitas pengelolaan PLBN Aruk ke depan tinggal hanya memerlukan pembenahan secara organisatoris dan administratif.

Fasilitas yang belum tersedia hingga dewasa ini adalah ketersediaan terminal bus dan truck, petugas Dinas Perhubungan Darat, perbankan, pemberian modal usaha bagi penduduk sekitar perbatasan. Ada pemberitaan bahwa perbankan segera akan dibangun masih dalam lingkungan 
PLBN Aruk. Keberadaan terminal bus dan truck juga sedang dalam proses pengerjaan, yang diperkirakan pertengahan 2018 ini akan selesai dan beroperasional seiring dengan dimasukkannya petugas Dinas Perhubungan Darat yang menangani arus transportasi darat, baik yang menuju dan keluar dari Aruk menuju Malaysia, maupun Singkawang, Sambas dan Pontianak. Hal ini sebagaimana dikatakan Manto Saidi, bahwa:

Koordinasi dengan Dinas Perdagangan dan UMKM khusus Kalimantan Barat regional Sambas. Sesungguhnya lebih dari sekedar koordinasi untuk urusan ini, Dinas Perdagangan bahkan melakukan kegiatan-kegiatan sosialisasinya dengan mengambil tempat di PLBN Aruk. Bahkan ketika PLBN Aruk masih bernama UP3LB, secara rutin Dinas Perdagangan, Dinas Perindustrian melakukan kegiatan, berbagai kegiatan di PLBN Aruk, semuanya menghadapi salah satu kendala terbesar belum bisanya kendaraan di situ lewat.

Selama ini Aruk belum bisa ditembus, maka kalau negara ingin mengembangkan perekonomian, hanya perekonomian engan skala jenis barang untuk keperluan sehari-hari saja, tidak untuk mendongkrak pertumbuhan ekonomi sebagaimana diamanatkan oleh Presiden Joko Widodo, juga diharapakan oleh Bupati Sambas dan pejabat lainya, serta seluruh komponen masyarakat. Mereka berharap agar PLBN Aruk ini menjadi pertumbuhan ekonomi kawasan perbatasan, termasuk termasuk seluruh kawasan Kabupaten Sambas.

Manto Saidi kemudian juga melanjutkan bahwa "Saya hanya bisa mengatakan bahwa kalau kita ingin membangun secara paripurna PLBN Aruk, maka regulasinya harus disempurnakan, aparatnya juga harus dilengkapi, tanpa itu PLBN Aruk, tidak lebih sebagai monumen, tempat orang berselfi ria". Pernyataan Manto Saidi tersebut dapat dijadikan masukan bagi pemerintah pusat, karena secara konsep dan operasional apa yang dikatakan dapat diterima dan sudah memiliki relevansi dengan pengalaman serupa di tempat dan waktu yang berlainan.

Ketiga, faktor struktur birokrasi. Pengelolaan PLBN Aruk belum terjalin secara kesatupaduan, yaitu masing-masing badan atau institusi yang terlibat masih memiliki struktur organisasi tersendiri, masih memiliki atasan dan pimpinan sendiri, sehingga berpotensi mengacaukan soal koordinasi antara bidang. Menurut Manto Saidi, sebaiknya untuk menyatupadukan gerak langkah operasional PLBN Aruk agar lebih lancar dan intensif, maka perlu dibentuk badan otoritas khusus yang menangani PLBN Aruk. Manto Saidi mencontohkan, "Kita itu membutuhkan lembaga semacam Angkasa Pura dan Pelindo di PLBN Aruk ini".

Sebagaimana diketahui Angkasa Pura merupakan badan pengelola operasional bandara, baik dari aspek imigrasi, beacukai, karantina, perdagangan, kepolisian, serta pengamanan, dan lain sebagainya, semuanya ditangani secara full authorithy oleh satu badan yang bernama Angkasa Pura. Begitu juga dengan Pelindo, sebuah badan otoritas yang berwenang penuh dalam pengelolaan pelabuhan laut, mulai dari arus masuk barang dan orang hingga antisipasi kasus selundupan serta pengamanan di pelabuhan. Semua proses tersebut baik secara administratif maupun operasional semuanya ditangani oleh badan otoritas yang bernama Pelindo. Harapan ke depan sebagaimana dikatakan Manto Saidi adalah pemerintah pusat akan segera membentuk 
badan otoritas khusus yang menangani dan mengelola PLBN Aruk, agar keberfungsian PLBN Aruk menjadi lebih efisien dan efektif, khususnya dalam peningkatan sosial dan ekonomi warga masyarakat di sekitar perbatasan.

\section{Penutup}

Dari uraian di atas bisa kita simpulkan bahwa telah terjadi pertumbuhan sektor sosial ekonomi sebagai akibat dampak kebijakan pembangunan Pos Lintas Batas Negara (PLBN) Aruk Desa Sebunga Kecamatan Sajingan Besar Kabupaten Sambas Kalimantan Barat. Peningkatan pembangunan di bidang sosial antara kondisi sebelum dan kondisi sesudah keberfungsian PLBN Aruk, dari semula rata-rata sebesar 60,62 menjadi sebesar 65,70 meskipun sebenarnya samasama dalam kategori "sedang". Hal ini disertai adanya fakta yang memperlihatkan telah adanya pertambahan jumlah sarana pendidikan dan ibadah yang dimaksud. Peningkatan pembangunan di bidang ekonomi antara kondisi sebelum dan kondisi sesudah keberfungsian PLBN Aruk, dari semula rata-rata sebesar 58,51 menjadi sebesar 65,06 walaupun sama-sama dalam kategori "sedang". Hal ini disertai adanya fakta yang memperlihatkan telah adanya pembangunan sarana umum, sarana perbankan dan pasar di kawasan tersebut.

Adapun faktor pendukung dari keberfungsian Pos Lintas Batas Negara (PLBN) Aruk Desa Sebunga Kecamatan Sajingan Besar Kabupaten Sambas Kalimantan Barat terkait pertumbuhan sektor sosial dan ekonomi, antara lain; sumber daya yang sangat memadai baik sumber daya alam/lahan atau sumber daya manusia. Kemudian dukungan tekonologi dan informasi yang diberikan oleh pengelola PLBN Aruk kepada masyarakat sekitar, di mana pada PLBN Aruk yang terdapat sarana wifi secara gratis untuk mempermudah arus komunikasi ke dunia luar kepada masyarakat. Dukungan dan kemudahan akses perekonomian lintas batas antar pengelola PLBN Aruk dengan masyarakat yaitu dengan adanya pasar yang membawa dampak mempermudah dan murah untuk mendapatkan sembako serta melakukan proses jual beli masyarakat. Sedangkan faktor penghambat dari keberfungsian Pos Lintas Batas Negara (PLBN) Aruk Desa Sebunga Kecamatan Sajingan Besar Kabupaten Sambas Kalimantan Barat terkait pertumbuhan sektor sosial dan ekonomi, antara lain; sulitnya komunikasi antar pengelola PLBN Aruk dan masyarakat terkait dengan sosialisasi dan pemahaman daerah perbatasan sehingga akan berdampak pada arus perkembangan perekonomian masyarakat. Sarana dan prasaranan infrastruktur umum yang meliputi sektor ekonomi, sosial dan administratif, sarana publik di wilayah perbatasan Indonesia dan Malaysia masih kurang seperti sarana telekomunikasi, air, gas serta tempat rekreasi. Selain itu faktor struktur birokrasi dalam melakukan kegiatan perekonomian yang belum memadai dalam memberi akses kemudahan modal dari pemerintah.

Dengan demikian, berdasarkan analisis dampak, secara detail potensi optimalisasi keberfungsian PLBN Aruk bagi perkembangan sosial dan ekonomi terletak pada aspek sinkronisasi peraturan perundang-undangan. Sebab, saat ini terjadi perbedaan penafsiran kewenangan dalam kerangka 
otonomi daerah, penggunaan istilah "wilayah perbatasan" dan "kawasan perbatasan" yang berbeda, penggunaan asas, prinsip dan tujuan terkait pengembangan kawasan PLBN Aruk, pengaturan objek yang sama dalam bermacam-macam peraturan dan instrumen hukum ratifikasi perjanjian batas negara dan titik koordinat yang masih sangat beragam. Selain aspek peraturan perundangundangan, potensi disharmonis keberfungsian juga terdapat pada aspek kelembagaan, yakni masih banyak lembaga/badan tidak efektif dan efisien, dan pengunaan data informasi yang tidak sama dalam mengambil suatu kebijakan.

Berdasarkan kondisi di atas, harmonisasi sosial dan hukum diarahkan pada upaya pengaturan pembangunan, pengembangan dan pengelolaan wilayah Aruk (dengan kawasan perbatasan masuk di dalamnya) secara efektif, efisien dan komprehensif yang berbasis teknologi untuk mencapai cita dan tujuan negara. Arah harmonisasi sosial dan hukum ini menghasilkan ide one regulation one body. Konsep pembaharuan hukum dengan ide one regulation one body diharapkan dapat membawa perubahan paradigma dalam pengembangan kawasan PLBN Aruk. Ide one regulation dikonkritkan dengan usulan pembentukan UU Wilayah NKRI yang secara substansial mengatur seluruh aspek kewilayahan NKRI, baik yang berada di bawah kedaulatan penuh, hak berdaulat ataupun hak-hak lain sebagaimana diatur hukum internasional, mulai dari bawah tanah sampai ruang angkasa. Tidak hanya itu, pengaturan itu juga mencakup pengaturan dan pembentukan badan yang berkompetensi dan berwenang atas kawasan perbatasan NKRI.

\section{Ucapan Terima Kasih}

Terima kasih pada seluruh narasumber yang telah berkenan diwawancarai penulis.

\section{Pendanaan}

Penulis tidak menerima bantuan pembiayaan untuk penelitian, kepenulisan (authorship), dan publikasi dari pihak manapun.

\section{Daftar Pustaka}

Abubakar, M. (2006). Analisa Kebijakan Pemanfaatan Pulau-pulau Kecil Perbatasan: Kasus Pulau Sebatik Kabupaten Nunukan Propinsi Kalimantan Timur. Sekolah Pascasarjana Institut Pertanian Bogor.

Elisabeth, A. (Ed.). (2016). Road Map Kebijakan Luar Negeri Indonesia (2015-2019) Mewujudkan Diplomasi Ekonomi Inklusif, Berbasis Lingkungan dan Berkelanjutan. Jakarta: Yayasan Pustaka Obor Indonesia.

Evaluasi dan Pengawasan Pengelolaan Perbatasan Negara. (2015). Pontianak: Badan Nasional Pengelola Perbatasan (BNPP).

Orlando, K. (2012). Evaluasi Dampak Kebijakan Pas Lintas Batas di Kecamatan Badau Kabupaten Kapuas Hulu Kalimantan Barat. Publica, 1(1). 
Firdaus

\section{Daftar Informan}

Manto Saidi, Kepala Pengelola PLBN Aruk, 15 Maret 2018, pukul 19.00 WIB.

Supriadi, Kesubid Fasilitasi Pelayanan PLBN Aruk, 17 Maret 2018, pukul 09.15 WIB.

\section{Tentang Penulis}

Firdaus adalah dosen kontrak Jurusan Ilmu Politik, Universitas Tanjungpura, Pontianak. Alumni Magister IImu Politik, Universitas Diponegoro ini menggeluti area riset seputar politik perbatasan. 